\title{
Impact Assessment of Increasing Population in Suburban Areas on Water Quality - A Case Study in Kitwe Township-Zambia
}

\author{
Sydney Sichilima, Cuthbert Makondo, and Cosmas Lungu
}

\begin{abstract}
Zambia's urban population is growing dramatically, driven by perceptions of better economic opportunities, infrastructure and services in urban areas. Water supply services, sanitation and other social amenities provision in urban areas like Lusaka, Kitwe, Livingstone and Ndola are getting overwhelmed and growth gauging from poorly planned residential settlements, growing energy demand, housing, poor road infrastructure accompanied by traffic jams have compounded the failure by local authorities and utility firms to cope with the demands of the rapidly increasing population. Due to high public demand for water, the water supply commercial utility companies fail to meet the consumption demand. It is from this view point that this research was conducted. The main objective was to assess the impact of increasing population on water quality in Kitwe Zambia. It has been concluded that both surface and groundwater is being polluted due to anthropogenic activities in the concerned town. The findings also point to that fact that water quality can be affected by increasing population.
\end{abstract}

Index Terms-Groundwater, pollution, population growth, surface water, water quality.

\section{INTRODUCTION}

Water is crucial for all life on earth. It plays an essential role in our health, economy, food production, and environment. Safe drinking water and freshwater are imperative for development and public health, since 21 of the 37 primary diseases in developing countries are related to water and sanitation [1]. The fact that our supply is finite has dire implications on our world population of nearly 7 billion people and growing. The global water consumption rate doubles every twenty years, a pace that is double the rate of population growth. If population and consumption trends persist, it is estimated that the demand for water will surpass its availability by $56 \%$, and 1.8 billion people will be living in regions of water scarcity by 2025 [2]. This situation is exacerbated by the fact that developing countries, already experiencing water-stress, often have the highest population growth rates-bringing more people into a region that already cannot support them.

Population growth is a direct determinant of increases in water demand for domestic uses. Another key demographic

Manuscript received March 5, 2014; revised May 26, 2014. This work was supported in part by the Copperbelt University, School of Mines and Mineral Sciences under Environmental Engineering Department.

The authors are with the Copperbelt University, P.O Box 21692, Kitwe, Zambia (e-mail: sydney.sichilima@cbu.ac.zm, cuthbert.makondo@cbu.ac.zm,cosmas.lungu@cbu.ac.zm). factor is change in the geographic distribution of population, which modifies the spatial pattern of demand for domestic use. Urbanization, in particular, through increased population density and the concentration of demand, can make the latter a serious constraint on local resources. Many third world cities are critical areas from the viewpoint of water supply.

\section{IMPACT OF POPULATION GROWTH ON SURFACE WATER}

Reference [3], human activities affect levels of river runoff principally by the direct withdrawal of water, the regulation of rivers, and land uses that change the surrounding environment and affect watershed dynamics. The population growth and socio-economic development mainly control water demand for different uses [4]. On my research I looked at how water quality in a Buchi Stream as been affected and polluted due human activities as a result of population growth.

There is high uncontrolled level of disposal of sawdust and ash in the Buchi Stream resulting from illegal sawmills, open burning of sawdust and charcoal burning. These activities have resulted in the narrowing and reduction in the depth of the stream and emissions of high levels of smoke from incomplete combustion of charcoal burning process is affecting the surrounding community. Despite sawdust and ash being inert materials if high levels are disposed in the stream it may have many chemical and physical impacts such as alteration of parameter like Dissolved Oxygen (DO), Biochemical Oxygen Demand or Biological Oxygen Demand (BOD), turbidity, Total Dissolved Solids and total suspended solids of water. Physical impact like narrowing and reduced depth may consequently result firstly in water stagnation and secondly drying up of the downward stream. Also high level eutrophication resulting from saw dust decomposition downstream was observed.

\section{A. Dissolved Oxygen}

One of the most important measures of water quality is dissolved oxygen. Oxygen, although poorly soluble in water, is fundamental to aquatic life. Without free dissolved oxygen, streams and lakes become uninhabitable to aerobic organisms, including fish and most invertebrates, observed by [5]. Table I above shows dissolved oxygen by Winkler's Method analysis before incubation period of five days. According to [6], the dissolved oxygen concentration shall be not less than $5.0 \mathrm{mg} / \mathrm{liter}$ at any time. Critically analyzing the results of Table I and Table II, I can confidently say that the dissolved oxygen demand falls in the range of the stipulated Zambian Standards even though results in Table II are clearly showing 
the decrease in dissolved oxygen along the stream where sawmills are located. This is clearly indicating that sawdust disposal in water bodies reduces dissolved oxygen demand which can pose a danger to aquatic life. I observed that, sawmills operations along rivers has an adverse effect on the physicochemical parameters of the water bodies like turbidity, $\mathrm{pH}$, temperature, Nitrate, phosphate, width and depth. Sawdust disposal and charcoal burning along the Buchi Stream has come about due to population growth in Kitwe.

TABLE I: DISSOLVED OXYGEN $\left(\mathrm{DO}_{1}\right)$ BEFORE FIVE DAYS

\begin{tabular}{|l|c|c|c|}
\hline & Initial (ml) & Final (ml) & $\begin{array}{c}\text { Dissolved } \\
\left(\mathrm{DO}_{1}\right) \mathrm{ml}\end{array}$ \\
\hline Blank & 8.6 & 16.2 & 7.6 \\
\hline Sample A & 16.2 & 24.4 & 7.4 \\
\hline Sample B & 24.4 & 32.6 & 8.2 \\
\hline Sample C & 32.6 & 41.6 & 9.0 \\
\hline Sample D & 41.6 & 48 & 6.4 \\
\hline
\end{tabular}

TABLE II: $\mathrm{DO}_{5}$ AFTER FIVE DAYS

\begin{tabular}{|l|c|c|c|}
\hline & $\begin{array}{l}\text { Initial } \\
(\mathrm{ml})\end{array}$ & $\begin{array}{l}\text { Final } \\
(\mathrm{ml})\end{array}$ & $\begin{array}{l}\text { Dissolved } \\
\left(\mathrm{DO}_{5}\right) \mathrm{ml}\end{array}$ \\
\hline BLANK & 0.0 & 7.2 & 7.2 \\
\hline Sample A & 7.2 & 12.4 & 5.2 \\
\hline Sample B & 12.4 & 19.8 & 7.4 \\
\hline Sample C & 19.8 & 27.6 & 7.8 \\
\hline Sample D & 27.6 & 33.2 & 5.6 \\
\hline
\end{tabular}

Decrease in dissolved oxygen value is an indicator of water pollution. This disturbs the normal uses of water as the water body loses its dissolved oxygen and ends up in a deep pool of water where fish cannot survive [7].
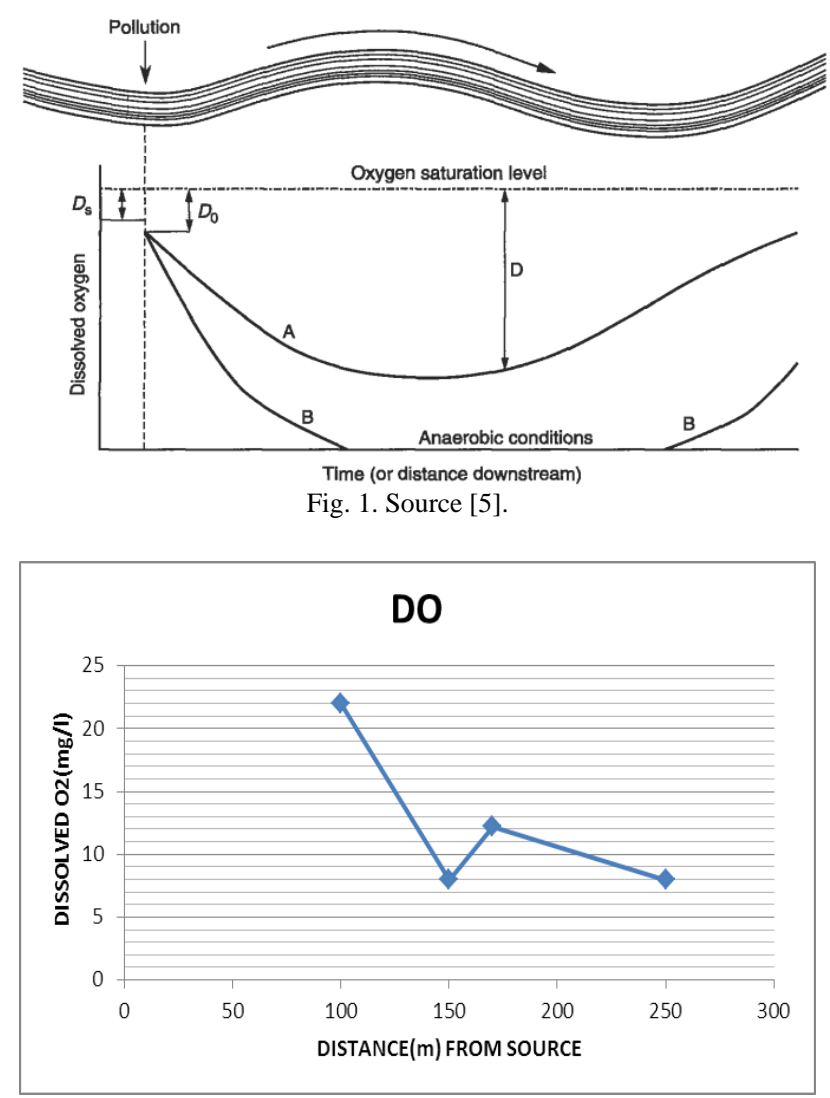

Fig. 2. dissolved oxygen.

In Fig. 1 above the dip in dissolved oxygen is referred to as a dissolved oxygen sag curve. Dissolved oxygen downstream from a source of organic pollution, curve A depicts an oxygen sag without anaerobic conditions; curve B shows an oxygen sag curve when pollution is concentrated enough to create anaerobic conditions, $D_{0}$ is the oxygen deficit in the stream after the stream has mixed with the pollutant, and $\mathrm{D}_{s}$ is the oxygen deficit of the upstream water [5].

Fig. 2 above shows the dissolved oxygen at the source and downstream where pollution is taking place along Buchi Stream. From Table III the source of the river point A has high dissolved oxygen as compared at B, C and D points where samples are taken at the points of sawdust and ash discharge into the stream from open burning of sawdust along the downstream. The results perfectly suit the standard for dissolved oxygen sag curve above (Fig. 1).

According to [8], when wastewater is disposed in the river water it consumes the dissolved oxygen of the river for the satisfaction of its BOD. This reduces the dissolved oxygen of the river water. If the D.O goes below $5 \mathrm{mg} / \mathrm{l}$ almost all the fish and the other aquatic life shall be destroyed. The dead fish will become organic matter that will further decompose and put more BOD and ultimately the whole of the DO of the fresh body of water shall be exhausted and it will convert into a polluted stale stinking useless body of water. If this body of water is a river moving fast with turbulence, it shall absorb more and more oxygen from the atmosphere and shall purify itself after some time and distance. This is known as the self purification of water [8]. But if more and more sewage is mixed in it (in between the self purification reach) it shall never purify itself and become a polluted body of foul water only. This is the present status of most of our rivers. In spite of many action plans of river protection and purification all the rivers in our country are in a bad position.

TABLE III: $\mathrm{DO}_{5}$ RESUlTS AGAINST DISTANCE FROM THE SOURCE OF BUCHI STREAM

\begin{tabular}{|c|c|c|}
\hline Trials & $\begin{array}{l}\text { Dissolved oxygen } \\
(\mathrm{mg} / \mathrm{l})\end{array}$ & $\begin{array}{l}\text { Distance from source } \\
(\mathrm{m})\end{array}$ \\
\hline $\mathrm{A}$ & 22 & $0-100$ \\
\hline $\mathrm{B}$ & 8 & $100-150$ \\
\hline $\mathrm{C}$ & 12.2 & $150-170$ \\
\hline $\mathrm{D}$ & 8 & $200-250$ \\
\hline
\end{tabular}

Samples at $\mathrm{C}$ in Table III shows an increase in dissolve oxygen because of self purification mechanism of the stream but the increase is small because of high pollution level than what the stream can handle.

The increase in population has forced many youths to get involved in timber trade which has a direct effect on water quality both surface water and groundwater. These results clearly show that the Buchi Stream has exceedingly exceeded the carrying capacity of different pollutants which adversely is affecting the ecosystem in the downward stream. Finally sample D shows a decrease in dissolved oxygen because of high sawdust and ash discharge from indiscriminate sawdust disposal and charcoal making activities at that point.

\section{B. Total Suspended Solids (TSS)}

Table IV below is showing Total Suspended Solids (TSS) results of the Buchi Stream using gravimetric method. 100 
$\mathrm{mg} / \mathrm{L}$ must not cause formation of sludge or scum in receiving water [6]. TSS are solids in water that can be trapped by a filter. TSS can include a wide variety of material, such as silt, decaying plant and animal matter, pulp mill, industrial wastes, and sewage. High concentrations of suspended solids can cause many problems for stream health and aquatic life. Samples taken at point B, C and D are clearly above the recommended standards. Similar to TSS, high concentrations of Total Dissolved Solids may also reduce water clarity, contribute to a decrease in photosynthesis, combine with toxic compounds and heavy metals, and lead to an increase in water temperature.

\section{Turbidity}

Table V below shows results of turbidity using spectrophotometer methods. Turbidity is a measure of the cloudiness of water- the cloudier the water, the greater the turbidity. Turbidity in water is caused by suspended matter such as clay, silt, and organic matter and by plankton and other microscopic organisms that interfere with the passage of light through the water [9]. Samples in Buchi Stream were collected where sawmills are located along the stream and downstream. Turbidity may not exceed levels detrimental to aquatic life. Turbidity in the receiving water, resulting from any discharge may not exceed 150 NTU (nephelometer turbidity units) at any time or 50 NTU as a monthly average. NTU are equivalent measures to FTUs (formazin turbidity units) and JTUs (Jackson turbidity units) [6]. All the values are above the standards which is a clear indication of water pollution due population growth in the suburban areas of Kitwe.

TABLE IV: TOTAL SUSPENDED SOLIDS (WAVELENGTH $810 \mathrm{NM}$ )

\begin{tabular}{|l|c|}
\hline Trials & UNITS $(\mathrm{mg} / \mathrm{l})$ \\
\hline CONTROL & 40 \\
\hline Sample A & 89 \\
\hline Sample B & 190 \\
\hline Sample C & 206 \\
\hline Sample D & 265 \\
\hline
\end{tabular}

TABLE V: TURBIDITY (WAVELENGTH $860 \mathrm{NM}$ )

\begin{tabular}{|l|l|}
\hline Trial & Units (NTU) \\
\hline Control & 89 \\
\hline Sample A & 170 \\
\hline Sample B & 172 \\
\hline Sample C & 178 \\
\hline Sample D & 261 \\
\hline
\end{tabular}

\section{Total Suspended Solids}

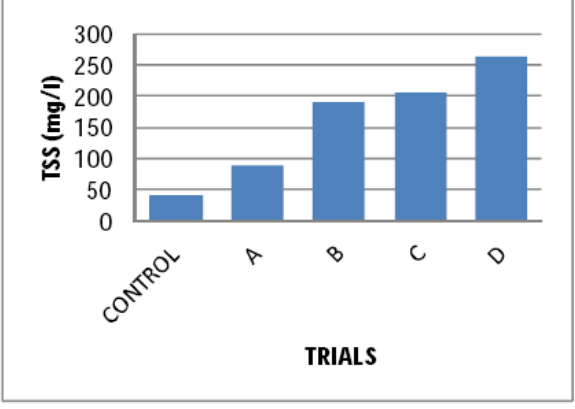

Fig. 3. Total suspended solids.

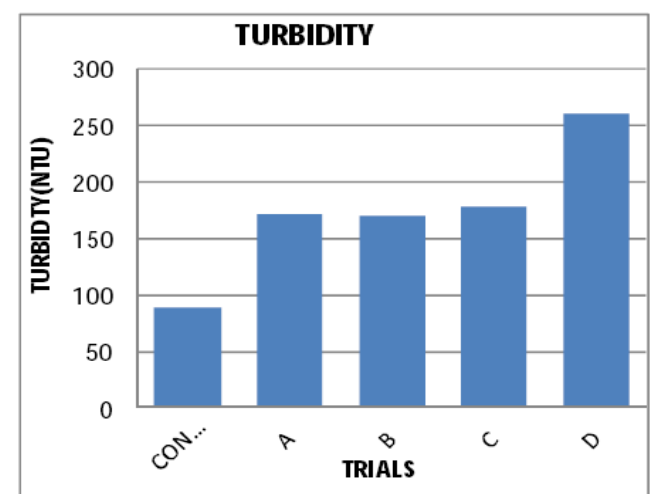

Fig. 4. Turbidity.

Fig. 4 above shows the turbidity of Buchi Stream due to sawdust disposal which has resulted from anthropogenic activities as the result of population increase in the suburban areas of Kitwe. This population explosion is due to urbanization and improved health facilities in Copperbelt Province, where Kitwe is located. Table V above shows the corresponding results of Fig. 4 above.

Fig. 3 and Fig. 4 turbidity and total suspend solid respectively shows similar trend of increase and decrease at corresponding points in relation to water pollution levels at point $\mathrm{A}, \mathrm{B}, \mathrm{C}$ and $\mathrm{D}$.

\section{Biochemical Oxygen Deman}

Fig. 5 below shows biological oxygen demand at the source and downstream where pollution is taking place.

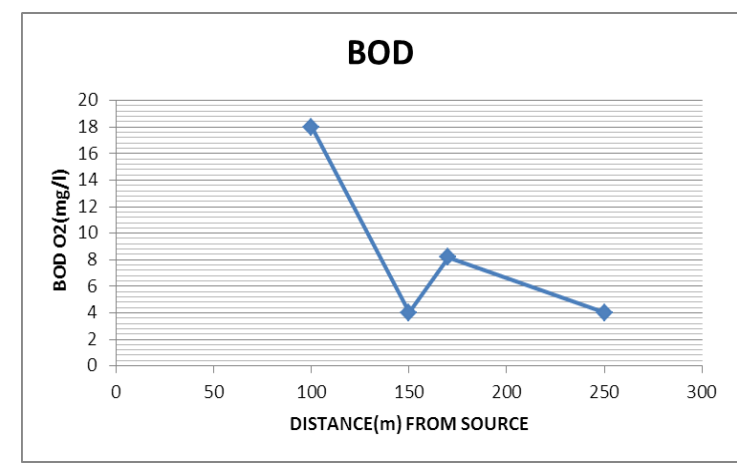

Fig. 5. Biochemical oxygen demand.

Referance [10] explains BOD as the amount of oxygen required by microorganism to break in down organic matters. It is used as an indicator of organic pollution of water.

The source of the stream has high BOD as compared to the second point which was sampled at point B where there is discharge of ash into the stream from open burning of sawdust along the stream. Third sample shows an increase in BOD because of self purification mechanism of the stream but the increase is small because of high pollution level than what the stream can handle. The fourth sample show in decrease in dissolved because of high sawdust and ash discharge from indiscriminate sawdust disposal and charcoal making activities at that point.

Water run-off from exposed piles of unburned and partially burned sawdust among the stream is contaminating streams and the surroundings. Ground water and land contamination may also result from leaching of tannic acids resulting from biological degradation of sawmill wastes. Disturbances of water flows in turn affect the wetting of the 
soil, the recharge of aquifers and rivers, the quality of freshwater and the per caput availability of water. Increased runoff due to deforestation has stripped soil off slopes and deposited it downstream, where it accumulates in the beds of streams and behind the new concrete dams", resulting in reduced storage in reservoirs and unstable water supply [3]. Urbanization is a major demographic trend all over the world also has distinct effects on surface water. When streets and other impermeable surfaces replace permeable soils and vegetation, the volume, velocity and temperature of local runoff are increased, reducing the base flow of rivers during dry periods.

Buchi Stream is not the only water body which is being adversely affected by population growth but also Kitwe Stream where I observed a lot of small scale businesses, like car wash, sawmills, restaurants, bars, etc. These unregistered small scale businesses have been established along Kitwe Stream to improve the livelihood of nearby communities as the result of population growth. I observed that Kitwe Stream is being heavily loaded with waste debris of vegetables, used cooking oil, chemicals of detergent pastes and other pollutants at Chisokone Market and effluents from industries along the Stream. Surface water is being polluted heavily because it is easy to access and there is no adequate sensitization on the importance of fresh water. With these observations on streams, it is an indicator of how other water bodies are getting affected as the result of population growth especially in suburban areas of Zambia.

\section{IMPACT OF POPULATION GROWTH ON GROUNDWATER}

The amount of water stored in the earth's crust may be of the order of 8 billion cubic kilometers, half of which is at depths less than $800 \mathrm{~m}$. This water inside the earth is about 35 times the combined storage of all the world's rivers, fresh water lakes, reservoirs, and inland seas, and is about one-third the volume of water stored in the Arctic and Antarctic ice fields, the glaciers of Greenland, and the great mountain systems of the world. All of this ground water, however, cannot be utilized because of physiographic limitations [11]. Protection of this valuable resource demands safeguarding groundwater quality against undesirable changes that occur directly when natural or artificial substances such as fertilizer are discharged into aquifers. Indirect effects due to the leaching of ions from soil or rock also must be addressed [12].

The importance of groundwater is often overlooked in most developing countries especially in the unplanned settlement, therefore I sought to assess and ascertain the quality of groundwater in three earmarked unplanned settlements of Kitwe Township, and the targeted compounds are Lungwa, Mulenga and Musonda Compounds respectively. Because of the climatic and human-induced instability of surface water, groundwater is important for water supply security. It is also a primary resource when surface water is scarce. During the recent decades it has supplied much of the water needed for burgeoning cities as well as for irrigation development. But groundwater aquifers are replenished only slowly, and human demands often exceed the natural recharge [3].
Table VI below shows winter results from randomly selected shallow wells in Luangwa, Mulenga and Musonda compounds respectively. Samples were collected during winter (Rain season) season in Table VI and Table VII shows second sampling collected in summer season. The depths of the wells assessed are in the range from 10 to 13 meters, radii of 0.45 to $1 \mathrm{~m}$ and pit latrines in the proximity of $15 \mathrm{~m}$ to $20 \mathrm{~m}$. The dumping sites were also taken into consideration as in these unplanned settlements there is poor solid waste management.

\section{A. Groundwater $p H$ in Winter}

Fig. 6 below shows the $\mathrm{pH}$ values obtained from the nine wells sampled for six months in winter period. I observed that from the entire three compound areas only 3 out of 9 sampled wells fell within the standard limits. The groundwater $\mathrm{pH}$ values were significantly lower in winter.

\section{B. Groundwater $p H$ in Summer}

Fig. 7 below shows the $\mathrm{pH}$ values obtained from the nine wells sampled for 4 months in summer period. I observed that from all the three compound areas only 5 out of 9 sampled wells fell within the standard limits see Fig. 7 below.

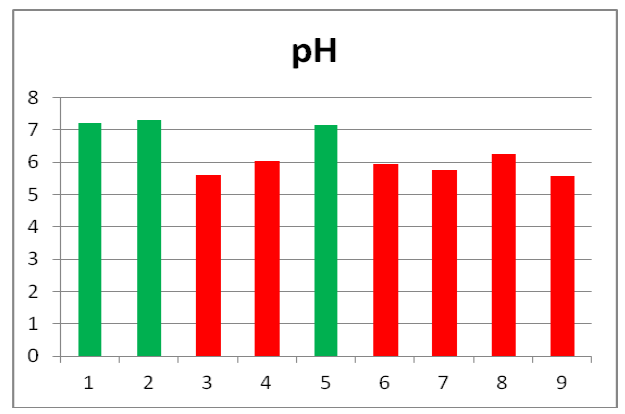

Fig. 6. $\mathrm{pH}$ in winter.

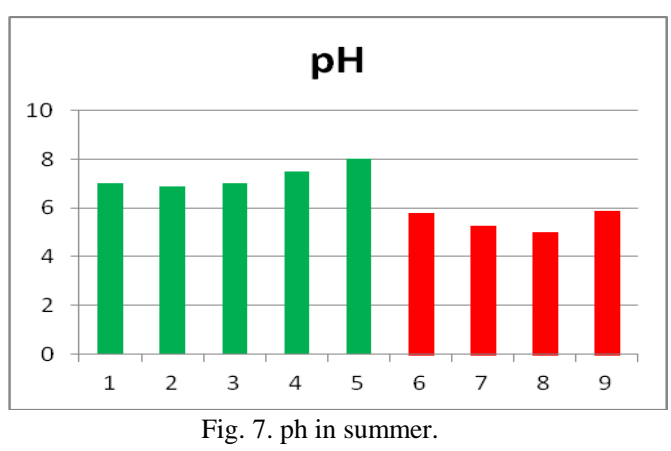

\section{Turbidity}

In groundwater the muddy or cloudy appearance of clay or such other particles that presents hindrance to the path of light is known as turbidity. It may not be harmful but even then from aesthetical point of view it should not exceed the allowable value.

All the wells from the three compounds exceeded the acceptable range standards (3 to 5 NTU) except one in Mulenga and one in Musonda Compounds from the nine wells sampled. The high level of turbidity indicates the prensence of total suspended solids (TSS) and total dissolved solids (TDS); hence this could give an indication of the prensence of bacteria, pathogens or particles that can shelter harmful organisms from disinfection process. In correlation 
with this results from Kitwe District Health Center explains the high record of water borne diseases in these compounds. Mulenga Compound as in 2011 recorded 53 cases of dysentry and a total of 205 cases of non blood diarrhoea from January to September [13].

\section{Nitrate and Phosphate}

From Table VI and Table VII, the values for nitrate obtained in Mulenga Compound are too high as compared to the standards set by Zambia Bureau of Standard on water quality. On the other hand, all the other 6 wells of all the compounds had their nitrates falling within the allowable standards. These polluted wells could be as a result of proximity of pit latrines and nature of surround soil. Another contributing factor is leaking leachate arising from solid waste disposal sites.

\section{E. Feacal Coliforms and Total Coliforms}

Fecal coliforms are particularly good indicator organisms because they are easily detected with a simple test, generally harmless (some strains are very pathogenic, but most are not), and do not survive long outside their host. The presence of fecal coliforms in a water sample does not prove the presence of pathogens, nor does the absence of fecal coliforms ensure the absence of pathogens. However, if a large number of fecal coliforms are present, there is a good chance of recent pollution by wastes from warm-blooded animals. This last point should be emphasized. The presence of coliforms does not prove that there are pathogenic organisms in the water, but indicates that such organisms might be present. A high coliform count is thus suspicious, and the water should not be consumed, even though it may be safe [9].

In Fig. 6 above FC is Feacal Coliforms and TC is Total Coliforms. All the wells had high values of coliforms. These high levels of coliforms indicate the presence of disease carrying organisms which pollute the wells. The rationale for higher levels of coliforms could be proximate of pit latrines were feacal matter could seep and leachates from dumping sites. According to World Health Organisation safe drinking water should not contain at all any coliforms.

TABLE VI: WINTER RESULTS

\begin{tabular}{|c|c|c|c|c|c|c|c|}
\hline Sampling point & $\mathrm{pH}$ & $\begin{array}{l}\text { Temp. } \\
\left({ }^{0} \mathrm{C}\right)\end{array}$ & $\begin{array}{l}\text { Turbidity } \\
\text { (NTU) }\end{array}$ & $\begin{array}{l}\text { Nitrates } \\
(\mathrm{mg} / \mathrm{l})\end{array}$ & Phosphates (mg/l) & $\begin{array}{r}\text { F.C } \\
100 \mathrm{ml}\end{array}$ & $\begin{array}{r}\text { T.C } \\
100 \mathrm{ml}\end{array}$ \\
\hline \multicolumn{8}{|c|}{ Mulenga Compound } \\
\hline Well 1 & 7.21 & 22.60 & 6.00 & 13.60 & 12.00 & 61.00 & 348 \\
\hline Well 2 & 7.30 & 22.20 & 0.00 & 70.00 & 6.80 & 93.00 & 615 \\
\hline Well 3 & 5.6 & 22.40 & 4.00 & 19.50 & 0.06 & 43.00 & 312 \\
\hline \multicolumn{8}{|c|}{ Musonda Compound } \\
\hline Well 1 & 6.05 & 23.40 & 33.00 & 2.80 & 0.20 & 31.00 & 88 \\
\hline Well 2 & 7.15 & 23.60 & 2.00 & 1.70 & 0.09 & 67.00 & 192 \\
\hline Well 3 & 5.95 & 22.80 & 22.00 & 0.60 & 0.04 & 63.00 & 168 \\
\hline \multicolumn{8}{|c|}{ Luangwa Compound } \\
\hline Well 1 & 5.75 & 22.6 & 17 & 0.35 & 0.01 & 76 & 236 \\
\hline Well 2 & 6.25 & 22.6 & 15 & 1.0 & $<0.01$ & 69 & 161 \\
\hline Well 3 & 5.58 & 22.7 & 11 & 1.0 & $<0.01$ & 33 & 484 \\
\hline \multicolumn{8}{|c|}{ Zambia Bureau Standards for Drinking Water } \\
\hline & $6.5-9$ & N/A & $3-5$ & 10 & $0.4-5$ & 0.00 & 20 \\
\hline
\end{tabular}

TABLE VII: SUMMER RESULTS

\begin{tabular}{|c|c|c|c|c|c|c|c|}
\hline Sampling point & $\mathrm{pH}$ & Temp. $\left({ }^{0} \mathrm{C}\right)$ & $\begin{array}{l}\text { Turbidity } \\
\text { (NTU) }\end{array}$ & Nitrates $(\mathrm{mg} / \mathrm{l})$ & Phosphates (mg/l) & F.C $100 \mathrm{ml}$ & T.C $100 \mathrm{ml}$ \\
\hline \multicolumn{8}{|c|}{ Mulenga Compound } \\
\hline Well 1 & 7.00 & 23.0 & 10.3 & 13.3 & 12.8 & 25 & 201 \\
\hline Well 2 & 6.90 & 22.20 & 2.00 & 73.00 & 6.23 & 30 & 415 \\
\hline Well 3 & 7.0 & 22.60 & 9.00 & 120.8 & 0.01 & 20 & 150 \\
\hline \multicolumn{8}{|c|}{ Musonda Compound } \\
\hline Well 1 & 7.50 & 23.00 & 21.00 & 2.80 & 0.20 & 14.00 & 75 \\
\hline Well 2 & 8.01 & 23.20 & 2.00 & 1.70 & 0.1 & 56.00 & 102 \\
\hline Well 3 & 5.80 & 22.90 & 15.00 & 0.60 & 0.04 & 60.00 & 91 \\
\hline \multicolumn{8}{|c|}{ Luangwa Compound } \\
\hline Well 1 & 5.25 & 22.6 & 13 & 0.35 & 0.01 & 45 & 198 \\
\hline Well 2 & 5.00 & 22.6 & 10 & 1.0 & $<0.01$ & 67 & 190 \\
\hline Well 3 & 5.90 & 22.7 & 13 & 1.0 & $<0.01$ & 39 & 450 \\
\hline \multicolumn{8}{|c|}{ Zambia Bureau Standards for Drinking Water } \\
\hline & $6.5-9$ & N/A & $3-5$ & 10 & $0.4-5$ & 0.00 & 20 \\
\hline
\end{tabular}




\section{RESUlTS AND DisCUSSION}

Water resources are as indispensable for industries as for other human activities on our planet. The population of Zambia as captured during the 2010 Census of Population and Housing was 13,092,666. This represents an increase of 32.4 percent from the population of 9,885,591 captured during the 2000 Census. The population in rural areas increased from $6,458,729$ in 2000 to $7,919,216$ in 2010, representing an increase of 22.6 percent between the two censuses. The population in urban areas grew by 51.0 percent from a population of 3,426,862 in 2000 to 5,173,450 in 2010. Lusaka Province had the largest population at 2,191,225 followed by Copperbelt Province with 1,972,317 [14]. Kitwe is the second largest city in terms of size and population in Zambia. With a population of 504,194 (2010 census provisional) Kitwe is one of the most developed commercial and industrial areas in the nation, alongside Ndola and Lusaka.

Given the above scenarios, it can be said that even though all wells had results for feacal coliforms exceeding recommendation ranges, the bacterial count for total coliforms still was very high. It can be generally observed that the cause of this level of contamination is the general hygiene condition prevailing in and around the wells. For some of the wells had no proper maintenance - no cover on top and this exposed water in the to various contamination vectors even soluble air pollutants like sulfur dioxide, particulate matter, and many more airbone diseases.

Unplanned settlement is due to population increase and urbanization particularly in developing countries is a major contributing factor in most peri-urban areas especiall here in Zambia. People are always migrating in search for employment and improved standard of living. The unsettling thing about the surges in urban populations is that urban development policies and urban planning arrangements in Zambia appear to be quite weak and are possibly lagging far behind the population explosions. Anecdotal evidence suggests that the population growth in the urban areas is rapidly overtaking and overwhelming the cities' infrastructure and social services. A few examples easily illustrate this point [1].

Diarrhea is a leading cause of morbidity and mortality in children less than five years old in the developing world. Consumption of fecally contaminated water is an important

route of transmission of enteric pathogens in many regions of the world lacking infrastructure to guarantee water quality and safe management of human waste.

\section{REFERENCES}

[1] C. Cheelo, "The urbanization dilemma: How rapid population expansion could clog up Zambia's main cities," Zambia Institute for Policy Analysis and Research -Opinion Piece Series, vol. 1, pp. 1-5, September, 2011.

[2] Water Facts \& Water Stories from Across the Globe, World Water Organization, New York, USA, 2010.

[3] Population and Water Resources, Food and Agriculture Organization, Roma, Italy, 2012.

[4] A. M. Aish. (September 2013). Drinking water quality assessment of the Middle Governorate in the Gaza Strip, Palestine. Water Resources and Industry. [Online] 4. pp. 13-20. Available: http://dx.doi.org/10.1016/j.wri.2013.09.004

[5] R. F. Weiner and R. A. Matthews, Environmental Engineering, $4^{\text {th }}$ ed. New York, USA: Elsevier Science, 2003, ch. 4, pp. 60-63, 82-92.

[6] Government of the Republic of Zambia, "Environmental Management Act No. 12 - 2011," Lusaka, Zambia: Government Printers, 2011.

[7] A. K. De, Environmental Engineering, New Delhi, India: New Age International (P) Ltd, 2009, ch. 5, pp. 68-69.

[8] R. C. Gaur, Basic Environmental Engineering, New Delhi, India: New Age International (P) Ltd, ch. 2, pp. 56-57, 100-102.

[9] Standard Methods for the Examination of Water and Wastewater, $20^{\text {th }}$ ed. American Public Health Association and others, Washington, D.C., 1998, pp. 2-11.

[10] D. Han, Concise Environmental Engineerig, Fredriksberg, Denmark: Ventus Publishing ApS, 2012, ch. 7, pp. 88-90.

[11] G. L. Asawa, Irrigation and Water Resources Engineering, New Delhi, India: New Age International (P) Ltd, 2008, ch. 4, pp. 121-122.

[12] L. D. Rajassoriyar, E. Boelee, M. C. C. M. Prado, and K. M. Hiscock. (October 2013). Mapping the potential human health implications of groundwater pollution in southern Sri Lanka. Water Resources and Rural Development. [Online] 1(2). pp. 27-42. Available: http://dx.doi.org/10.1016/j.wrr.2013.10.002

[13] Diarrhea Prevalence in Copperbelt Province Zambia, Kitwe District Health Office, Lusaka, Zambia, 2013.

[14] Government of the Republic of Zambia, "National analytical report," Lusaka, Zambia: Government Printers, 2012.

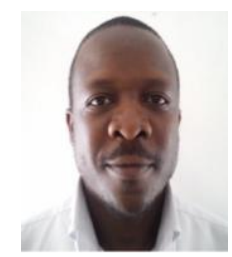

Sydney Sichilima was born in Zambia, Luanshya on August 7, 1979. He had been a member of The Copperbelty University (CBU) in 2012; Asia-Pacific Chemical, Biological \& Environmental Engineering Society (APCBEES) in 2014.

He obtained master's degree of engineering and technology in environmental engineering, at Kazan State Power Engineering University (KSPEU) in Kazan Russian Federation in 2009. In 2007, he obtained a bachelors degree in the same field at the same University. He joined the University of Zambia (UNZA) as a lecturer in 2010, then in 2011 joined the University of Africa (UoA) as the researcher and lecturer. Currently, he is working as a researcher, lecturer and consultant at The Copperbelt University. His main research interest is in 1) Implication of nanomaterials on water quality, 2) Nanotechnology and Environment, 3) Groundwater pollution modeling, 4) Quantifying total maximum daily load of rivers and streams

Mr. Sichilima is a member of Engineering Institute of Zambia (EIZ), Water Sanitation Association of Zambia (WASAZA) and Asia-Pacific Chemical, Biological\& Environmental Engineering Society (APCBEES). 